\title{
T-Cell Prolymphocytic Leukemia
}

National Cancer Institute

\section{Source}

National Cancer Institute. T-Cell Prolymphocytic Leukemia. NCI Thesaurus. Code C4752.

An aggressive T-cell leukemia, characterized by the proliferation of small to medium sized prolymphocytes with a mature T-cell phenotype, involving the blood, bone marrow, lymph nodes, liver, spleen, and skin. (WHO, 2001) 